\title{
Biodegradability and Adaptability Studies of Geothermal Wastewater in a Biological Treatment Plant
}

\author{
LUISA ROXANA POPESCU1*, CRISTINA DINU² \\ ${ }^{1}$ National Research and Development Institute for Industrial Ecology - Ramnicu Valcea Subsidiary, 1 Uzinei Str., 240050, Romania \\ ${ }^{2}$ National Research and Development Institute for Industrial Ecology - Bucharest, 71-73 Podu Dambovitei Str., 060650, Bucharest, \\ Romania
}

\begin{abstract}
The purpose of this study was to identify the optimal conditions for the operation of biological treatment plant by carrying out biodegradability tests for geothermal wastewaters with high salt content. The biodegradation tests for geothermal wastewaters were carried out in a discontinuous flow bioreactor. The phases of the biodegradation process were: adaptation of the biological sludge, control of the biological treatment process, experiments in the laboratory bioreactors (BATCH). The results of the biodegradability tests revealed that geothermal waters with high salt content influence the treatment process. The dilution of these waters with domestic water up to chlorine concentrations below $800 \mathrm{mg} \mathrm{L}^{-1}$, makes the purification process to have a good biodegradation yields for CCO-Cr (about 75\%) and CBO-5 (about $72 \%$ ). If these geothermal wastewaters are not diluted to concentrations lower than $800 \mathrm{mg} \mathrm{L}^{-1}$, the biological sludge after 6 days is mineralized, which makes the use of biological treatment plant to be impossible.
\end{abstract}

Keywords: geothermal waters, biodegradation, wastewater, mineral salts

The need for tests for biodegradability arose from the large-scale use of synthetic surfactants, or surface-active agents, soon after the Second World War. Bioremediation is an attractive alternative that has been used to eliminate or minimize the effects of pollutants, employing microorganisms with potential for biodegradation and being able to transform contaminants into less toxic substances or mineralizing them $[1,2]$. For the success of bioremediation technologies, the occurrence of microorganisms with the appropriate metabolic abilities is the most important requisite on pollutants-bioremediation [3-5]. Bioreactors have played an important role in the detoxification-of hazardous pollutants and have been successfully applied in ex-situ bioremediation strategies [6]. Bioreactors are basically tanks in which living organisms carry out biological reactions [7-9]. These types systems display as main advantage a larger control of environmental and physico-chemical conditions affecting rates and extents of microbial grow th and oil transformation such as oxygen supply, optimal $\mathrm{pH}$, temperature and specific quantity nutrient providing an increase on biodegradation [7]. On the other hand, in environments where the ex-situ bioremediation can hardly be used, bioreactors can be also efficiently applied to provide the biostimulation of autochthonous microorganisms growing in the presence of oil for subsequent reintroduction in the affected environment as strategy of bioremediation of polluted [10].

The use of geothermal water plays an important role for enviromental and for the economy due to its therapeutic properties and the possibility of its use in heating the population [11 - 14]. The existence of important thermal water deposits in the north-west part of Romania facilitates the use of this energy form on the local area, for different purposes, ensuring the saving of a quantity of conventional fuels [ $15-17]$.

The geothermal waters from Calimanesti county is procured from 3 springs, from a depth of about 3000 meters. The temperature of these geothermal waters ranges between 90 and $97^{\circ} \mathrm{C}$. The physico-chemical and geothermal properties of geothermal waters create a series of problems for urban wastewater treatment plants.

The technical problems faced by the urban wastew ater treatment plant are due to the high content of mineral salts (chlorides, sodium, etc.) of these geothermal waters [1825].

In this study, the biodegradation tests have been carried out for geothermal wastewaters with high salt content, in order to identify optimal solutions for the operation of the treatment plants that contain this geothermal water.

\section{Experimental part}

Materials and methods

Reagents

Reagents used were of recognized analytical quality (Merck, Fluka, etc.) which were used as such. Distilled water was used for quality 2 according to ISO 3696. Determination of quality indicators was done according to standards water in force specific to each indicator analyzed.

\section{Aparatus and methods}

Experimental studies on the physico-chemical characterization of the studied samples were performed by electrochemical methods using a Multiparameter Orion Star A 215 and a Oxygenometer HANNA (for pH, CBO5, and Dissolved oxygen concentration); by volumetric methods using calibrated biurettes (for chlorides and CCO$\mathrm{Cr})$; by gravimetric methods using a analytical balance Precision XB 220 (for filterable residue and suspensions). All methods used were standardized methods and are in accordance with current legislation.

Biodegradability experiments were carried out in two laboratory bioreactors. The microscopic analysis of inoculation sludge was performed with a NID-3479 laboratory microscope.

\section{Results and discussions}

The experimental studies for biodegradation of geothermal wastewater were conducted in discontinuous laboratory bioreactors. 
For the adaptation studies of sludge was used biological sludge, which was harvested from the recirculation system of the Râmnicu Valcea City wastewater treatment plant. The microscopic analysis of the biological inoculation sludge revealed a well-structured biocoenosis with a diversified microfauna, represented by free ciliate (Aspidisca, Euphlotes) and fixed (Vorticella and Operularia), which indicates a good purification. The active sludge also represented good characteristics for sedimentation around $100 \mathrm{~cm}^{3} / \mathrm{g}$ (table 1$)$.

Control of the biological treatment process in laboratory bioreactors, was carried out by checking the influent/ effluent at every new feed and by determining the following indicators: $\mathrm{pH}$, organic load expressed by CCO-Crand CBO5 , inorganic load expressed by chlorides, sodium and filterable residue.

For biomass from bioreactors, where biodegradation experiments were performed, were determined periodically $\mathrm{pH}$, concentration of biological sludge, sludge index, dissolved 02 concentration, and also daily was monitored at microscope the biocenos of the active sludge.

Because the geothermal wastewater, used to feed laboratory bioreactors, contains large amounts of mineral salts, for the experiments was used dilute geothermal wastewater in a favorable ratio for the development of the bacterial population in good conditions.

In parallel were used two laboratory bioreactors for biodegradability studies. The feed water from the first bioreactor contain geothermal wastewater and domestic water, and feed water for the second bioreactor was composed of the domestic water with contain of geotermal wastewater, from the biological treatment plant and domestic water.

For the initial tests, for first laboratory bioreactor was used geothermal wastewater and domestic water in the ratio of 1:3 for 3 days and 1:2 for another 3 days. For the second bioreactor was used domestic water with geothermal water content, undiluted. At the beginning of its adaptation, the biological sludge from both bioreactors had good sedimentation properties (IVN $=114.3 \mathrm{~cm}^{3} / \mathrm{g}$ for the first bioreactor and IVN $=92.1 \mathrm{~cm}^{3} / \mathrm{g}$ for the second bioreactor) (table 1).

Initially, the first bioreactor was fed with geothermal wastewater and domestic water in a ratio of 1:3 for 3 days, then fed with geothermal wastewater and domestic water in a ratio of 1:2 for another 3 days. After 6 days adaptation of the sludge with geothermal wastewater diluted with domestic water, it was observed that the sludge was mineralized. The volume indice of the sludge were 34.7 $\mathrm{cm}^{3} / \mathrm{g}$ for the first bioreactor (table 1).

The second laboratory bioreactor was fed for 6 days with domestic water containing geothermal water from the municipal wastewater treatment plant without dilution. After the 6 days adaptation of the sludge with domestic water containing geothermal water it was observed that the sludge was mineralized. The volume indice of the sludge were $45.0 \mathrm{~cm}^{3} / \mathrm{g}$ (table 1 ).

Thus, for the two types of geothermal water studied, after about 6 days of adaptation of the sludge to the studied waters, it was observed that the sludge was mineralized. The volume index of the sludge has reached values less than $50 \mathrm{~cm}^{3} / \mathrm{g}$ (table 2).

In table 2 the optimum values for the sludge volume index (Mohlman Index) are displayed.

For the subsequent tests, in the first bioreactor was used, geothermal wastewater and domestic water in the ratio of 1:10, and for the second bioreactor, was used domestic water with geothermal water content in the ratio of $1: 2.5$. Adaptation of the sludge was performed for 7 days, during which time the influent and the effluent of the bioreactors were analyzed.

\begin{tabular}{|c|c|c|c|c|c|c|}
\hline \multicolumn{2}{|c|}{ QUALITY INDICATORS } & U.M. & \multicolumn{4}{|c|}{ DETERMINED VALUES } \\
\hline \multicolumn{3}{|c|}{ Date of sampling } & $\begin{array}{c}06.04 . \\
2017\end{array}$ & $\begin{array}{l}9.04 . \\
2017\end{array}$ & $\begin{array}{c}10.04 . \\
2017\end{array}$ & $\begin{array}{c}11.04 . \\
2017\end{array}$ \\
\hline \multicolumn{3}{|c|}{ Name of samples } & 295RV & 301RV & $305 R V$ & 317RV \\
\hline \multirow{4}{*}{$\begin{array}{c}\text { First } \\
\text { laboratory } \\
\text { bioreactor, } \\
\text { the initial test }\end{array}$} & $\mathrm{pH}$ & unit. pH & 6.4 & 5.4 & 5.7 & 5.6 \\
\hline & $\begin{array}{l}\text { Sludge } \\
\text { concentration }\end{array}$ & $g / L$ & 3.9 & 8.0 & 8.9 & 8.6 \\
\hline & $\begin{array}{l}\text { Dissolved } \\
\text { oxygen } \\
\text { concentration }\end{array}$ & $\mathrm{mg} / \mathrm{L}$ & 6.4 & 7.0 & 6.9 & 6.9 \\
\hline & $\begin{array}{l}\text { Volume index } \\
\text { (IVN) or Mohlman } \\
\text { index }\end{array}$ & $\mathrm{cm}^{3} / \mathrm{g}$ & 114.3 & 56.9 & 38.8 & 34.7 \\
\hline \multicolumn{3}{|c|}{ Name of samples } & 296RV & 302RV & $306 \mathrm{RV}$ & 318RV \\
\hline \multirow{4}{*}{$\begin{array}{c}\text { Second } \\
\text { laboratory } \\
\text { bioreactor, } \\
\text { the initial test }\end{array}$} & $\mathrm{pH}$ & unit. pH & 6.6 & 6.51 & 6.69 & 6.77 \\
\hline & $\begin{array}{l}\text { Sludge } \\
\text { concentration }\end{array}$ & $\mathrm{g} / \mathrm{L}$ & 6.4 & 7.6 & 8.4 & 8.5 \\
\hline & $\begin{array}{l}\text { Dissolved } \\
\text { oxygen } \\
\text { concentration }\end{array}$ & $\mathrm{mg} / \mathrm{L}$ & 5.4 & 5.5 & 5.6 & 5.8 \\
\hline & $\begin{array}{l}\text { Volume index } \\
\text { (lvw) or Mohlman } \\
\text { index }\end{array}$ & $\mathrm{cm}^{3} / \mathrm{g}$ & 92.1 & 47.3 & 45.0 & 45.0 \\
\hline
\end{tabular}

Table 1

QUALITY INDICATORS ANALYZED FOR BIOLOGICAL SLUDGE SAMPLES FROM THE TWO LABORATORY BIOREACTORS USED FOR THE INITIAL TESTS

\begin{tabular}{|l|c|}
\hline \multicolumn{1}{|c|}{ The quality of the sludge } & $\begin{array}{l}\text { Sludge volume index values or } \\
\text { "MohIman Index", Ivv }\left(\mathrm{cm}^{3} / \mathbf{g}\right)\end{array}$ \\
\hline $\begin{array}{l}\text { sludge with low sedimentation } \\
\text { properties ("swollen" sludge) }\end{array}$ & $\geq 120$ \\
\hline good sludge & $\leq 80$ \\
\hline sludge very good & $>50$ \\
\hline sludge mineralized & $\leq 50$ \\
\hline
\end{tabular}

Table 2

THE OPTIMUM VALUES FOR THE SLUDGE VOLUME INDEX (MOHLMAN INDEX) 
On the 7th day, after the two bioreactors were fed with the samples studied, water samples were taken from them at 5 min, 1, 3, 6 and $24 \mathrm{~h}$ and were characterized physicochemical (table 3). On the eighth day, water samples were taken again at the same time as the 7th day.

For both bioreactors the organic load expressed by CCO$\mathrm{Cr}$ and $\mathrm{CBO} 5$ was followed. Values for $\mathrm{CCO}-\mathrm{Cr}$ were between $19.2 \mathrm{mgO}_{2} / \mathrm{L}$ and $76.8 \mathrm{mgO}_{2} / \mathrm{L}$ for the first bioreactor and between 19.2 and $67.2^{2} \mathrm{mgO} / \mathrm{L}$ for the second bioreactor. And for $\mathrm{CBO} 5$ the values were between 6.0 and $21.5 \mathrm{mgO}_{2} / \mathrm{L}$ for the first bioreactor and between 6.0 and $17.5 \mathrm{mgO}_{2}^{2} \mathrm{~L}$ for the second bioreactor (table 3).

Also, for both bioreactors the inorganic loading expressed by filtration residue, chlorides and sodium was also followed. Filtrable residue values ranged between 964.0 and $1285.0 \mathrm{mg} / \mathrm{L}$ for the first bioreactor and between 700.0 and $865.00 \mathrm{mg} / \mathrm{L}$ for the second bioreactor. For chlorides the values were between 453.8 and $467.9 \mathrm{mg} / \mathrm{L}$ for the first bioreactor and between 290.7 and $304.9 \mathrm{mg} / \mathrm{L}$ for the second bioreactor. And for sodium, its values ranged betw een 133.6 and $202.5 \mathrm{mg} / \mathrm{L}$ for the first bioreactor and between 87.7 and $64.7 \mathrm{mg} / \mathrm{L}$ for the second bioreactor (table 3).
At the same time with the analysis of the effluents of the bioreactors, the analysis of the biological sludge samples was carried out by monitoring the $\mathrm{pH}$, the biological sludge concentration, the volume index of the sludge and the dissolved oxygen concentration. Biological sludge from the two laboratory bioreactors had good sedimentation properties at the start of the biodegradability test (volume index of sludge around $75 \mathrm{~cm}^{3} / \mathrm{g}$ ). After $24 \mathrm{~h}$ it was observed that the sludge had sedimentation properties as good as the beginning with a volume index of sludge of about $55 \mathrm{~cm}^{3} / \mathrm{g}$ for both laboratory bioreactors.

So we can say that at 1:10 dilutions for geothermal waste water and 1:2.5 dilutions for domestic water with geothermal water content, the biological sludge was not mineralized and had the sedimentation properties as good as the beginning of the tests.

The biodegradation yields obtained for the two bioreactors are shown in the table 4. The biodegradability yields for the first bioreactor were between $75 \%$ for CCO$\mathrm{Cr}$ and 3\% for chlorides, and for the second bioreactor were between $66.7 \%$ for CCO-Cr and $4.7 \%$ for chlorides.

Table 3

THE PHYSICO-CHEMICAL CHARACTERIZED FOR WATER SAMPLES THAT WERE TAKEN FOR BOTH BIOREACTORS AT $5 \mathrm{~min}, 1 \mathrm{~h}, 3 \mathrm{~h}, 6$ AND $24 \mathrm{~h}$ IN 7 TH DAY AND 8TH DAY. THE BIODEGRADATION YIELDS, FOR QUALITY INDICATORS DETERMINED INITIAL TESTS

\begin{tabular}{|c|c|c|c|c|c|c|c|c|}
\hline \multicolumn{2}{|c|}{ QUALITY INDICATORS } & U.M. & \multicolumn{6}{|c|}{ DETERMINED VALUES } \\
\hline \multicolumn{3}{|c|}{$\begin{array}{c}\text { Date of sampling } 25.05 .2017 \text {, } \\
\text { time interval }\end{array}$} & $\begin{array}{c}5 \\
\text { minutes }\end{array}$ & 1 hours & 3 hours & 6 hours & 24 hours & \multirow{3}{*}{$\begin{array}{c}\text { Biodegradation } \\
\text { yield }\end{array}$} \\
\hline \multicolumn{3}{|c|}{ Name of samples } & 460RV & 461RV & 462RV & 463RV & 464RV & \\
\hline \multirow{6}{*}{$\begin{array}{c}\text { First } \\
\text { laboratory } \\
\text { bioreactor, } \\
\text { BATCH I }\end{array}$} & $\mathrm{pH}$ & $\begin{array}{c}\text { unit. } \\
\mathrm{pH}\end{array}$ & 6.5 & 6.9 & 6.5 & 6.9 & 6.9 & \\
\hline & $\mathrm{CCO}-\mathrm{Cr}$ & $\mathrm{mg} / \mathrm{L}$ & 76.8 & 48.0 & 28.8 & 28.8 & 19.2 & $75.0 \%$ \\
\hline & CBO5 & $\mathrm{mg} / \mathrm{L}$ & 21.5 & 14.4 & 8.9 & 8.6 & 6.0 & $72.3 \%$ \\
\hline & $\begin{array}{l}\text { Filterable } \\
\text { residue }\end{array}$ & $\mathrm{mg} / \mathrm{L}$ & 1285.0 & 1220.0 & 1175.0 & 1108.0 & 964.0 & $25.0 \%$ \\
\hline & Sodium & $\mathrm{mg} / \mathrm{L}$ & 202.5 & 133.6 & 133.6 & 133.6 & 133.6 & $34.0 \%$ \\
\hline & Chlorides & $\mathrm{mg} / \mathrm{L}$ & 467.9 & 467.9 & 467.9 & 460.9 & 453.8 & $3 \%$ \\
\hline \multicolumn{3}{|c|}{ Name of samples } & $465 \mathrm{RV}$ & $466 \mathrm{RV}$ & 467RV & $468 \mathrm{RV}$ & $469 \mathrm{RV}$ & \multirow[b]{2}{*}{$\begin{array}{c}\text { Biodegradation } \\
\text { yield }\end{array}$} \\
\hline \multirow{6}{*}{$\begin{array}{l}\text { Second } \\
\text { laboratory } \\
\text { bioreactor, } \\
\text { BATCH I }\end{array}$} & $\mathrm{pH}$ & $\begin{array}{l}\text { unit. } \\
\mathrm{pH}\end{array}$ & 6.8 & 7.1 & 6.7 & 7.2 & 7.0 & \\
\hline & $\mathrm{CCO}-\mathrm{Cr}$ & $\mathrm{mg} / \mathrm{L}$ & 48.0 & 38.4 & 38.4 & 28.8 & 19.2 & $60,0 \%$ \\
\hline & CBO5 & $\mathrm{mg} / \mathrm{L}$ & 13.0 & 11.2 & 11.2 & 8.6 & 6.0 & $54,1 \%$ \\
\hline & $\begin{array}{l}\text { Filterable } \\
\text { residue }\end{array}$ & $\mathrm{mg} / \mathrm{L}$ & 865.0 & 840.0 & 820.0 & 784.0 & 700.0 & $19,1 \%$ \\
\hline & Sodium & $\mathrm{mg} / \mathrm{L}$ & 87.7 & 87.7 & 87.7 & 87.7 & 64.7 & $26,2 \%$ \\
\hline & Chlorides & $\mathrm{mg} / \mathrm{L}$ & 304.9 & 304.9 & 304.9 & 297.8 & 290.7 & $4,7 \%$ \\
\hline \multicolumn{3}{|c|}{$\begin{array}{c}\text { Date of sampling 26.05.2017, } \\
\text { time interval }\end{array}$} & $\begin{array}{c}5 \\
\text { minutes }\end{array}$ & 1 hours & 3 hours & 6 hours & 24 hours & \multirow{3}{*}{$\begin{array}{c}\text { Biodegradation } \\
\text { yield }\end{array}$} \\
\hline Nam & of samples & & 470RV & 471RV & 472RV & 473RV & 474RV & \\
\hline \multirow{4}{*}{$\begin{array}{c}\text { First } \\
\text { laboratory } \\
\text { bioreactor, }\end{array}$} & $\mathrm{pH}$ & $\begin{array}{l}\text { unit. } \\
\mathrm{pH}\end{array}$ & 7.0 & 7.3 & 7.4 & 7.3 & 7.4 & \\
\hline & $\mathrm{CCO}-\mathrm{Cr}$ & $\mathrm{mg} / \mathrm{L}$ & 67.2 & 48.0 & 19.2 & 38.4 & 19.2 & $71.4 \%$ \\
\hline & CBO5 & $\mathrm{mg} / \mathrm{L}$ & 17.5 & 13.4 & 6.0 & 11.2 & 6.0 & $66.0 \%$ \\
\hline & $\begin{array}{l}\text { Filterable } \\
\text { residue }\end{array}$ & $\mathrm{mg} / \mathrm{L}$ & 1224.0 & 1136.0 & 1028.0 & 1108.0 & 1028.0 & $16.0 \%$ \\
\hline \multirow[t]{2}{*}{ ВАТCH II } & Sodium & $\mathrm{mg} / \mathrm{L}$ & 218.8 & 218.8 & 172.9 & 209.6 & 172.9 & $21.0 \%$ \\
\hline & Chlorides & $\mathrm{mg} / \mathrm{L}$ & 623.9 & 609.8 & 588.5 & 595.6 & 588.5 & $5.7 \%$ \\
\hline \multicolumn{3}{|c|}{ Name of samples } & $475 \mathrm{RV}$ & 476RV & 477RV & $478 \mathrm{RV}$ & $479 \mathrm{RV}$ & \multirow[b]{2}{*}{$\begin{array}{c}\text { Biodegradation } \\
\text { yield }\end{array}$} \\
\hline \multirow{4}{*}{$\begin{array}{c}\text { Second } \\
\text { laboratory } \\
\text { bioreactor, }\end{array}$} & $\mathrm{pH}$ & $\begin{array}{l}\text { unit. } \\
\mathrm{pH}\end{array}$ & 7.2 & 7.4 & 7.5 & 7.2 & 7.5 & \\
\hline & $\mathrm{CCO}-\mathrm{Cr}$ & $\mathrm{mg} / \mathrm{L}$ & 48.0 & 48.0 & 19.2 & 19.2 & 16.0 & $66.7 \%$ \\
\hline & CBO5 & $\mathrm{mg} / \mathrm{L}$ & 12.0 & 13.4 & 5.6 & 5.8 & 4.8 & $60.0 \%$ \\
\hline & $\begin{array}{l}\text { Filterable } \\
\text { residue }\end{array}$ & $\mathrm{mg} / \mathrm{L}$ & 744.0 & 744.0 & 740.0 & 688.0 & 656.0 & $12.60 \%$ \\
\hline \multirow[t]{2}{*}{ BATCH II } & Sodium & $\mathrm{mg} / \mathrm{L}$ & 167.7 & 163.7 & 163.7 & 154.5 & 145.3 & $13.40 \%$ \\
\hline & Chlorides & $\mathrm{mg} / \mathrm{L}$ & 404.2 & 404.2 & 382.9 & 382.9 & 382.9 & $5.30 \%$ \\
\hline
\end{tabular}


Table 4

THE BIODEGRADATION YIELDS OBTAINED FOR THE TWO BIOREACTORS AFTER THE TWO DAYS OF BIODEGRADATION TESTS (BATCH I AND BATCH II)

\begin{tabular}{|l|c|l|c|}
\hline \multicolumn{4}{|c|}{ Biodegradability test for the first bioreactor } \\
\hline Quality indicator & $\begin{array}{c}\text { Biodegradation yield } \\
\text { after 24 hours }\end{array}$ & \multicolumn{1}{|c|}{ Quality indicator } & $\begin{array}{c}\text { Biodegradation } \\
\text { yield after 24 hours }\end{array}$ \\
\hline BATCH I (Date of sampling 25.05.2017) & \multicolumn{1}{|c|}{ BATCH II (Date of sampling 26.05.2017) } \\
\hline CCO-Cr & $75.0 \% ;$ & CCO-Cr & $71.4 \%$ \\
\hline CBO-5 & $72.3 \%$ & CBO-5 & $66.0 \%$ \\
\hline Sodium & $34.0 \% ;$ & Sodium & $21.0 \%$ \\
\hline Filtrable residue & $25.0 \%$ & Filtrable residue & $16.0 \%$ \\
\hline Chloride & $3.0 \%$ & Chloride & $5.7 \%$ \\
\hline \multicolumn{4}{|c|}{ Biodegradability test for the second bioreactor } \\
\hline BATCHT(Date of sampling 25.05.2017) & BATCHII (Date of sampling 26.05.2017) \\
\hline CCO-Cr & $60.00 \% ;$ & CCO-Cr & $66.70 \%$ \\
\hline CBO-5 & $54.1 \%$ & CBO-5 & $60.00 \%$ \\
\hline Sodium & $26.2 \% ;$ & Sodium & $13.40 \%$ \\
\hline Filtrable residue & $19.10 \%$ & Filtrable residue & $12.60 \%$ \\
\hline Chiloride & $4.70 \%$ & Chloride & $5.30 \%$ \\
\hline
\end{tabular}

Table 5

THE LIMIT VALUES ALLOWED BY H.G. 352/2005, ANNEX NO. 3 TABLE NO. 1- (NTPA 001) FOR WASTEWATER

\begin{tabular}{|l|c|c|}
\hline QUALITY INDICATORS & U.M. & $\begin{array}{c}\text { H.G. 352/2005 } \\
\text { Annex no. 3 Table no. 1-(NTPA 001) } \\
\text { Limit values allowed }\end{array}$ \\
\hline pH & unit. pH & $6.5-8.5$ \\
\hline CCO-Cr & $\mathrm{mg} / \mathrm{L}$ & 125 \\
\hline CBO5 & $\mathrm{mg} / \mathrm{L}$ & 25 \\
\hline Filterable residue & $\mathrm{mg} / \mathrm{L}$ & 2000 \\
\hline Sodium & $\mathrm{mg} / \mathrm{L}$ & - \\
\hline Chlorides & $\mathrm{mg} / \mathrm{L}$ & 500 \\
\hline
\end{tabular}

From the physico-chemical characterization of the effluents of the laboratory bioreactors (BATCH I and II), it is observed thatall the quality indicators analyzed fall within the limits imposed by H.G. 352/2005 (NTPA 001) NTPA001 / 2002 (table 5).

\section{Conclusions}

In this study biodegradability tests of geothermal wastewater and domestic water with geothermal water contentwere carried out. These biodegradability tests were performed to see the biodegradation yields of the samples analyzed and to find the conditions in which the biological treatment plant containing these waters can function without the sludge being mineralized.

From the experimental studies carried out with discontinuous flow laboratory bioreactors, it was observed that the best biodegradation yields (for CCO-Cr about $75 \%$ and $\mathrm{CBO}-5$ about $72 \%$ ) were obtained for 1:10 ratio for geothermal wastewater and domestic water and respectively for the ratio of 1:2.5 for domestic water with geothermal water content and domestic water. It is also noted that the removal rate for chlorides was very low (comprised between 5.7 and 3\%), for filterable residue was between 25 and $12.6 \%$, and for sodium was included between 34 and $13.4 \%$.

The biodegradation yields are influenced by high chlorine concentrations that have a biological sludge mineralization effect. For good sewage treatment, the chlorine concentration should be less than $800 \mathrm{mg} / \mathrm{L}$.

The data obtained from the experimental studies are important for obtaining the necessary technical data for a good function of wastewater treatment plant, which contain domestic water with geothermal water content.

Acknowledgement: The results presented in this study has been obtained with the support of the Program NUCLEU PN 16-25 0207.

\section{Reference}

1.CERQUEIRA, V.S., HOLLENBACH, E.B., MABONI, F., CAMARGO, F.A.O., PERALBA, M.C.R., BENTO, F.M., World J. Microbiol. Biotechnol, 28, 2012, p. 1203-1222.

2.PUIU, D., GALAON, T., CRUCERU, L.V., NICULESCU, M., MIHALACHE, M., PASCU, L.F., POPESCU, M., Rev. Chim.(Bucharest), 68, no. 8, 2017, p.1740-1743.

3.AL-WASIFY, R.S., HAMED, S.R., Int. J. Bacteriol. 2014, p. 1-8. 4.WOINAROSCHI, A., SINGUREANU, C., Rev. Chim.(Bucharest), 68, no. 12, 2017, p.2812-2816

5.BUMBAC, C., MANEA, E. E., TIRON, O., BADESCU, V.R., Rev. Chim. (Bucharest), 69, no. 1, 2018, p.10-13.

6.KUYUKINA, M.S., IVSHINA, I.B., SEREBRENNIKOVA, M.K., KRIVORUTCHKO, A.B., PODOROZHKO, E.A., IVANOV, R.V., LOZINSKY, V.I., Int. Biodeterior. Biodegrad. 63, 2009, p. 427-432.

7.CHIKERE, C.B., CHIKERE, B.O., OKPOKWASILI, G.C., Biotech. 2, 2012, p. 53-66.

8.STEFANESCU, M., NECHIFOR, G., BUMBAC, C., IONESCU, I., TIRON, O., Rev. Chim.(Bucharest), 69, no. 1, 2018, p.31-33

9.MARIN, N.M., TIRON, O., PASCU, L.F., COSTACHE, M., LAZAR, M. N., BADEA, I. A., Rev. Chim.(Bucharest), 69, no. 1, 2018, p.38-44

10.MALIJI, D., OLAMA, Z., HOLAIL, H.,. Int. J. Curr. Microbiol. Appl. Sci. 2, 2013, 1-18.

11.ROMOCEA, T., GHERGHELES, C., PANTEAREV. E., Rev. Chim. (Bucharest) 63, no. 6, 2012, p. 636-640

12.SONG, F.M., KIRK, D.W., GRAYDON, J.W., CORMACK, D.E., Journal of Corrosion Science and Engineering, 3, 2002, p. 24

13.POPA, L., RADULESCU, M., DINU, A., VELCIU, L., BRANZOI, I.,V., Rev. Chim. (Bucharest), 59, no. 2, 2008, p. 140

14.PATZAY, G., Electrochimica Acta, 43, nr.1-2, 1998, p.137

15.RICHTER, S., HILBERT, L.R., THORARINSDOTTIR, R.I., Corrosion Science, 48, nr. 7, 2006, p.1770

16.VASILESCU, M., VASILESCU, I., Rev. Chim. (Bucharest), 60, no. 10, 2009 , p. 23

17.AFIF, A., IGNATIADIS, I., Proceedings of the World Geothermal Congress, Florence, Italy, 1995, vol 4, p. 2491 
18.HALLDOR, A., HREFNA, K., Geothermics, 21, 1992, p. 869

19.POPA, L., RADULESCU, M., DINU, A., VELCIU, L., BRANZOI, I.,V., Rev. Chim. (Bucharest), 59, no. 2, 2008, p. 140

20.VASILESCU, M., VASILESCU, I., Rev. Chim. (Bucharest), 60, no. 10, 2009 , p. 23

21.SONG, F.M., KIRK, D.W., GRAYDON, J.W., CORMACK, D.E., J ournal of Corrosion Science and Engineering, 3, 2002, p. 24

22.RICHTER, S., HILBERT, L.R., THORARINSDOTTIR, R.I., Corrosion Science, 48, nr. 7, 2006, p.1770
23.ADRIAN, L., MANZ, W., SZEWZYK, U., GÖRISCH ,H., Applied and Environmental Microbiology, 64, 1998, p. 496-503

24.ZHANG, H., LU Y., SHIA ,Y., WANG, T., XING, Y., DAWSON, R. W., Environmental Science \& Policy, 8, 2005, p. 153-160

25. IORDACHE, M., PAVEL, V. L., MYUNGHEE, L., IORDACHE,? I., Environmental Engineering and Management J ournal, 8, no. 2, 2009, p. 201-206

Manuscript received: 20.02 .2018 